\title{
“The Mind Develops Wings": The Famished Road
}

\section{Christopher Ringrose}

\section{(2) OpenEdition}

1 Journals

Electronic version

URL: https://journals.openedition.org/ces/5334

DOI: $10.4000 /$ ces.5334

ISSN: 2534-6695

\section{Publisher}

SEPC (Société d'études des pays du Commonwealth)

\section{Printed version}

Date of publication: 1 April 2013

Number of pages: 33-44

ISSN: 2270-0633

\section{Electronic reference}

Christopher Ringrose, "'The Mind Develops Wings": The Famished Road", Commonwealth Essays and Studies [Online], 35.2 | 2013, Online since 17 April 2021, connection on 23 July 2021. URL: http:// journals.openedition.org/ces/5334 ; DOI: https://doi.org/10.4000/ces.5334

\section{(c) (i) (3) $\Theta$}

Commonwealth Essays and Studies is licensed under a Licence Creative Commons Attribution - Pas d'Utilisation Commerciale - Pas de Modification 4.0 International. 


\section{"The Mind Develops Wings": The Famished Road}

A number of illuminating recent critical readings of The Famished Road tend to abstract a particular allegorical or political significance from the text. However, Okri's later narratives, such as Dangerous Love, Astonishing the Gods and In Arcadia, suggest that spirituality and the power of the imagination are the defining features of his work. Spirituality pervades the whole of The Famished Road - a fact which can make more specific allegorical readings appear limiting. The novel is best viewed through the intersection between material and spiritual journeys, and the way these relate to the novel's multifaceted depiction of social conditions.

The mind either learns to live within the closed labyrinth of the conjoining of death and life; Or the mind develops wings, and soars.

Ben Okri, In Arcadia 209.

understand things slowly - digest thoroughly - act swiftly - re-dream the world - restructure self.

Ben Okri, Dangerous Love 363.

This essay seeks to emphasize the importance of spirituality and the power of the imagination in Ben Okri's The Famished Road. Indeed, Okri's later narratives, such as Dangerous Love, Astonishing the Gods and In Arcadia, suggest that these themes have remained a defining feature of his work. There have been a number of illuminating recent critical readings of The Famished Road - including Jonathan Highfield's environmental perspective, Clare Barker's concern with its representation of disability, and Gerd Bayer's invocation of Paul Gilroy's idea of "conviviality" to suggest Okri's thinking about colonialism and exploitation. I will argue, however, that these critics, like others before them, tend to abstract a particular allegorical or political significance from the text as a whole, relating it to national and political debates. Okri's distinctive use of allegory, however, deals with these concerns under a larger over-arching frame which allows him to restlessly interrogate notions of matter and spirit, the senses and imagination. Spirituality pervades the whole narrative, a fact which can make more specific allegorical readings appear limiting. I will suggest that the best way to view The Famished Road is through intersection between material and spiritual journeys, and the way these journeys relate to the novel's multifaceted depiction of social conditions.

Three of Ben Okri's post-Famished Road novels, Dangerous Love, Astonishing the Gods and In Arcadia, represent his sustained attempt to define contemporary creativity, spirituality and the power of the imagination. These books could in fact be said to set themselves up against over-simple notions of "postmodernism" as a cultural dominant. Okri is certainly not cowed by routine postmodern scepticism from using terms such as beauty, freedom and imagination. The Famished Road famously combines the tight, centripetal world of the ghetto, which many have seen as a version of 1950 or 1960s Lagos, with the limitless and unbounded world of spirits, which are "free in infinity" (487). At first sight, the Lagos of Dangerous Love seems, on the contrary, one of extreme limitations and very little freedom. Like Azaro in The Famished Road, its Nigerian hero 
Omovo exists in a world of restrictions, which affect his human development. The Lagos compound in which he lives is both familial and communal, with its "twin strips of bungalows $[\ldots]$ airless trapped heat, the stuffy smells and the bustling noises. [...] The cement ground was grey, dirty and full of potholes. Above, the sky could be seen through the corrugated eaves" (6). The communal bathroom, with its "overpowering" stench and "scum that had collected around the drain" (7) represents unwanted spatial intimacy, abject communion, that persists throughout the text.

However, there are alternative dimensions to Omovo's existence. His artistic talent, his love for Ifeyiwa (the wife of a neighbour), his soaring and idealistic meditations, together with his sense of human and national potential, all expand his sense of self. It is Okri's special talent to be able to fuse the material, spiritual and ideological aspects of existence within a single fiction, and the fact that Omovo's Lagos is a dangerous lifethreatening place is what makes his hero's inspirational development towards the end of the novel so moving. A person needs to be brave to live a full life there. But then, as Azaro's father says at the end of The Famished Road, "the man whose light has come on in his head, in his dormant sun, can never be kept down or defeated. We can redream this world and make the dream real" (498).

Astonishing the Gods, Okri's tour de force of fantastic fiction, appeared in 1995. This book sets aside The Famished Road's dualism, as represented by the material world of Azaro's father's gigantic labours and the seductive or frightening voices of the spirit world. What is "real" in Astonishing the Gods is the world of the imagination, the spirit or soul. Its nameless hero engages in a quest for spiritual knowledge, and completes it. However, the opening pages of the novel are grounded in metaphors relating to nationality and ethnicity, since the central character is an invisible man:

He was born invisible. His mother was invisible too, and that was why she could see him. His people lived contented lives, working on the farms, under the familiar sunlight. [...] It was in books that he first learnt of his invisibility. He searched for himself and his people in all the history books he read and discovered to his youthful astonishment that he didn't exist. (3)

Robert Fraser (88) and Ralph Pordzik (49) agree that this trope of invisibility is related to Ralph Ellison's novel Invisible Man, where African-Americans live the paradox of being on the one hand defined by appearance (by "a different sun," as Okri puts it in In Arcadia [107]), and on the other hand invisible, in the sense that Okri suggests here. But when the hero of Astonishing the Gods arrives by ship in an apparently deserted city, the trope of invisibility modulates, for the city is populated and created by The Invisibles, philosopher-citizens whose dream is to create the first universal civilization of justice and love (155). Their values are founded on the concepts of creativity and grace, and their invisibility and devotion to spiritual values and civic virtues is fostered by their invisibility. As we learn at the end of the text, the purpose of invisibility is perfection (155). Since The Famished Road, Okri has continued to counterpoint inner and outer spaces, and this is the case here - except that this fabulous, poetic narrative is the closest Okri has come to an otherworldly fiction, an evocation of untrammelled human vision. Astonishing the Gods is an inspirational text that counsels trust in intuition, respect for learning, the need to take artistic creativity seriously, the need to avoid cynicism and easy scepticism, and the renunciation of ego. Like all Okri's books, it ends with an extended meditative and inspirational coda. 
In Arcadia (2002) marks out Ben Okri as transnational writer, in the sense in which the term has been proposed by Andreas Huyssen. Huyssen sees the concept of transnationalism as a way of overcoming the false dichotomy between the local and the global, counteracting and complicating the "argument that only local culture or culture as local is good, authentic and resistant, whereas global cultural forms must be condemned as manifestations of cultural imperialism, i.e., Americanization" (13). In Arcadia's Lao, a black intellectual (112) and celebrity television presenter, narrates part of the story of the making of a documentary film about the idea of Arcadia; at other times he is the locus of free indirect speech and thought. In Arcadia blends the novel form with travel writing, art criticism, allegory, meditation, aphorisms, autobiographical fiction, dialogue and inspirational text, reminding one of Bakhtin's insight that the novel itself originated from a blend of many textual genres and sources. The structure of In Arcadia also reminds readers that, however different the forms of Okri's fictions may be, they dwell on certain enduring preoccupations, which are as central to Dangerous Love and Astonishing the Gods as to The Famished Road. Among these are his Romantic project to reinstate the concept of spirituality in modern life, outside the institutions of organized religion; his sense of the importance of nationality and ethnicity; his questioning of the relationship between the spiritual and political health of individuals and nations; and his testing of spatial and geographical parameters, both metaphorically and literally. The juxtaposition of the material and spiritual realms had been present in Dangerous Love, where Omovo's skill in gaining a place on the heaving, infrequent, blue danfo Lagos buses (217-24) is a counterpoint to his painting and his ecstatic, space-annihilating meditations by the sea (361-4).

At the end of In Arcadia, Okri's film-makers visit the Louvre, to view Nicolas Poussin's beautiful, haunting painting Et in Arcadia Ego. In Virgil's fifth eclogue, two shepherds come across the tomb of the poet Daphnis - who, in Okri's words was "gifted and beautiful and [...] died young" (208). In Poussin's painting, three shepherds and a shepherdess walking in the Arcadian landscape have come across a tomb, and are trying to decipher its inscription Et in Arcadia Ego - "I too have lived in Arcadia." Lao, and Okri, ponder this painting, and the inscription, at length. It provides the springboard for the reflections which, in a characteristic Okri strategy, make up the conclusion of the novel (one thinks of Dad's speeches at the end of The Famished Road, the rapt rhetoric that concludes Astonishing the Gods, and Omovo's epiphany, "THE MOMENT" towards the end of Dangerous Love). Repressive politics and the brutal inevitability of death (since citizenship of Arcadia was no refuge from death for the Everyman beneath the tomb), are set against beauty, art and the possibility of imaginative transcendence. Okri makes the painting's challenge explicit through Lao's thoughts on the possibility of transcendence:

There is transcendence in Virgil, the poet.

There is no transcendence in Poussin.

There is just the bare statement of fact, an impenetrable fact: "I too lived in Arcadia."

This fact is a labyrinth without any exit. It is closed.

The mind either learns to live within the closed labyrinth of the conjoining of death and life;

Or the mind develops wings, and soars. (209)

After this homage to the imagination, the book concludes with a more political speculation: the enigma of revolution and social change, and whether it will come from within 
or without. Like Astonishing the Gods, which moves from the opening anger at African "invisibility" to glorify the power of thought, emotion, imagination and self-actualisation, In Arcadia ends with an extended spiritual testament, the conclusion of which is a counsel against despair, melancholy and cynicism: "living is the place where gods play within mortal flesh" (229-30).

Even this brief account of three of the novels published after The Famished Road suggests the consistency of Okri's themes, and his eclecticism in his choosing material and settings. It should not surprise us that two of Okri's best critics, Ato Quayson and Douglas McCabe, are able to affiliate The Famished Road to distinctly different cultural traditions. Quayson provides a meticulous and authoritative account of the relationship between the book and its sources in Nigerian writing, Yoruba oral memory and mythmaking. McCabe, on the other hand, argues for the importance of "New Age spiritual discourse" (McCabe 2). ${ }^{1}$ As the Nigerian critic Ben Obumselu points out in an insightful recent essay, both of these contexts (and several others) interest and inspire Okri. Obumselu notes, however, that in seeking to locate "the most important cultural vector shaping The Famished Road" (McCabe 2) in a millennial vision of world history, McCabe is in danger of mistaking Azaro's voice for Okri's, and of "foreclose[ing] the possibility of a much broader interpretation in which all the elements which he mentions mutually adjust their functions within a developing imaginative form" (Obumselu 2). I will suggest later that there are good reasons (most evident at the end of the novel) for McCabe's conflating the voices of Azaro and Okri, but in general I am in agreement with a number of Obumselu's arguments, such as his refusal to privilege Azaro's perspective, and his account of Okri's "imaginative freedom" in "picking and choosing and combining motifs, symbols and episodes from many cultures," (4) his "art of oblique forms" (6).

Rather than seek such a "broad interpretation," critics have often been tempted either to read The Famished Road as an extended political or national allegory, or to tease out one particular strand of its texture and make that predominant. As Stephen Levin points out in his study of the work of Amit Chaudhuri, allegory generates correspondences: the surface of the text encodes another, parallel strata of reference. It is writing with a double meaning, often with latent political referents (Levin n.p.). Fredric Jameson, in an essay on the nature of Third World writing published four years before The Famished Road, pointed to what he saw as "the primacy of national allegory in thirdworld culture," (12) suggesting that "private individual destiny" often functions in Third World literature as an allegory for the nation as a whole. Indeed, postcolonial writing has, as Levin points out, been seen by some to work a series of allegorical variations on "the primal crime of empire" (n.p.).

A number of features of The Famished Road lend themselves to the deciphering of schematic and symbolic meanings, based on national and historical codes. The existence of two worlds, one material, one spiritual; the generic names (Mum, Dad, The Photographer, the Old Man, the Landlord); the political turmoil and violence connected to the birth of a nation; the spectres of slavery; the forest, sometimes threatening, sometimes threatened, that stands at the edge of human dwellings; the road, in all its manifestations; Dad's punishing combat with a variety of adversaries in the boxing ring;

1. Douglas McCabe has developed his view of The Famished Road in an essay in this issue of Commonwealth Essays and Studies. 
the narrator, caught between human affection and seductive voices promising an alternative reality. But even though these symbolic arenas and events often resolve themselves eventually into some variant of pre-colonial, colonial and post-colonial Africa, the relation of these historical periods to the events of the novel is tantalizing, and has proved elusive for a succession of critics. The Famished Road certainly echoes Derrida's insight that the present is made up of multiple temporalities. If it is a ghost story, in which Azaro is haunted by those who pursue him from the other side, then it is also a story of a spectral nation, in the sense in which the term spectrality has been deployed by Derrida to evoke the way that dead generations may haunt the living:

you will never be your name, you never have been, even when, and especially when you have answered to it. The name is made to do without the life of the bearer, and is therefore always somewhat the name of someone dead. (39)

The Famished Road's multivalency and productivity in the face of interpretation mean that critics have brought certain elements into prominence in persuasive ways. In 2012, Jonathan Highfield, in his essay "No Longer Praying on Borrowed Wine: Agroforestry and Sovereignty in Ben Okri's Famished Road Trilogy" uses Frantz Fanon's The Wretched of the Earth to read the novel in environmental terms as an intervention into the debate about global capitalism, food production and local sustainability: "food sovereignty [...] is one of the defining principles of true liberation in a Fanonian sense, and food sovereignty in West Africa is inextricably bound up with forest use and protection" (152). He relates The Famished Road, too, to the work of Wangari Maathai, the founder of the Green Belt Movement, and the need for food production to come "under the control of those who plant it for their tables, for their families and friends, and for their livelihood and their very survival (153). Highfield highlights the importance of the connections between colonialism and independence in West Africa, and the place of the forest in the trilogy. For him, the allegorical patterns in The Famished Road are patent: "the global movement of capital [is] represented by the market where Azaro's father carries sacks of concrete on his back," (146) for example, and the "release of the antelope has to be read as a symbolic attempt to free both the human and the nonhuman from the greed of global capitalism" (Highfield 151; Famished Road 449). After reading Highfield's article it is impossible to return to The Famished Road without registering the title anew, or the pervasive emphasis on buying, procuring, preparing, cooking, sharing and eating food within the text - its place in family and community life and in the material as opposed to the spiritual world. But for readers interested by Okri's exploration of spirituality, Highfield's emphasis on national symbolism can become limiting, because it is so allencompassing. The old woman of the forest represents "the true secret history" of Africa (Famished Road 113; Highfield 147). "Madame Koto serves as the embodiment of independence" (Highfield 148), as indicated by her monstrous pregnancy (Famished Road 306). And, of course, an abiku nation keeps being reborn (567).

In an essay in her 2011 book on Postcolonial Fiction and Disability: Exceptional Children, Metaphor and Materiality, Clare Barker proposes a different emphasis. She draws on the way the abiku child is othered, and the fact that "many of [the novel's] central characters [Azaro included] are disabled," (161) and uses concepts such as "ethical witnessing," (185) unconventional behaviour, and spatial dislocation to question earlier accounts of the book as postcolonial allegory. Barker draws on the work of disability theorists such as Sharon L. Snyder and David T. Mitchell, whose Cultural Locations of Disability calls for 
a holistic understanding of the disabled, to focus on Azaro's "unique ontology $[\ldots]$ and its intervention into discourses of nation-construction" (161). Suggesting that most accounts of the book begin with "a cursory recognition of indigenous belief systems and/or the representation techniques of magical realism" before "read[ing] straight through Azaro's exceptional abiku status," (163) Barker prefers to regard the novel as anticipating contemporary theories of the ethical and political dimensions of disability. Thus, she reintroduces politics into the centre of the novel, in the process outflanking those like Andrew Smith, who had criticized The Famished Road for its abstraction from concrete politics (Barker 160).

Gerd Bayer's recent account of the novel sees it as inviting us to transcend historical patterns of thinking about colonialism and exploitation, and thus anticipating Paul Gilroy's idea of "conviviality." Gilroy's After Empire (2004) invites his readers to move beyond the essentialism of racial categories towards "a different sense of the human." Only by moving beyond "racial hierarchy," Gilroy suggests, will Western discourse and social reality avoid the creation of "infrahuman life forms," (xii) a phenomenon linked both to the War on Terror and some of the twentieth-century genocidal atrocities. Gilroy sees "conviviality" as a kind of hospitality that embraces differences and includes neighbourly attitudes without judging them, and for Bayer this "uncannily matches the kind of human engagement and, indeed, conviviality slowly developed in Ben Okri's The Famished Road" (78).

Gerd Bayer's reading puts forward an inspiring vision of the book, but it too is selective. Is the wild boar feast in Chapter Eleven of Book One really a place where "friends, neighbours, strangers, and children, all come together through conversation, eating, drinking, and singing. [where] little [...] seems to take away from the positive energy and togetherness created by this convivium" (81)? My own impression is that the sharing of food, like environmental awareness and Azaro's position as a child with a disability (or different abilities) surfaces at times within The Famished Road and subsides at others. In fact, many other themes operate in the same way. On the other hand, the Okri theme that seldom slips from the reader's view is the question of what constitutes spirituality, and how it relates to work and exploitation.

Chapter Eleven of Book One is certainly worth examining. Food is often an index of anxiety and confusion in The Famished Road; in this instance, Dad has found a wild boar in a trap, killed it, and hopes to feed numbers of people with its flesh (although he never repeats this exploit, even when the family is desperately hard up). It soon becomes apparent that there is not sufficient food for all the people invited to the feast. As Azaro anxiously notes:

People had talked themselves into such a hunger that the food barely went round. Like the miracle of the multiplying fishes in reverse, the food diminished before it got to the guests. The rice was swiftly consumed, the boar disappeared into the capacious stomachs of the ravenous gathering, the stew dried out in the pots, and the people stared at their plates in drunken puzzlement. (53)

The convivial feast turns into a fiasco, just as the resentment-fuelled rebellion against the politicians' bad milk evolves into revenge and retribution. Azaro's readiness to supply an analogy from the gospels is not matched by awareness of Christian tradition elsewhere in his narration, even though everyone says "Amen" to Mum's prayer. (In fact, Azaro's narrative perspective is one of the major points of ambiguity in the novel.) 
Soon, the feast degenerates further: Mum accuses another woman of lying (43); Dad spoils the rhythm of the women's song by tapping on an empty bottle (42); when the Landlord is woken up he asks "Where's my rent?" (49). Spirits attend the gathering and are seen by Azaro. He screams when ghosts emerge from the photographer's flashbulbs (45), but with characteristic nonchalance the narrative emotion soon switches to a different register, as "sweet voices singing" (48) tempt Azaro to depart from this world to one of eternal feasting. Much has been made, critically, of the double world in which Azaro lives: the world of the real and the mundane, and the world of the spirits. In practice, both exist on a level of grotesquerie that make the attribution of the term "spiritual" to the "other" world, and non-spiritual to the human dimension, seem like an over-simplification. The more convincing moments of spirituality, or self-effacing commitment, come from the trio of Mum, Dad and Azaro when each glimpses the concerns and humanity of the others. The spirit messengers are alarming, abrupt and disturbing, but so are the human activities amongst which Azaro lives - a world of alternating abuse and violence and tenderness.

The feast represents one of Dad's first steps towards transcendence and celebration. The material and spirit worlds conspire to subvert his attempt, and one can understand why Azaro and his family live for much of the novel at a sustained pitch of anxiety. In Azaro's case this can be related to his pursuit as a fugitive, but it goes beyond that. Anxiety about threats from organizations and thugs, from his father's own unpredictable behaviour, his mother's variableness, poisons, foods, spies in the form of Madame Koto, and verbal abuse from neighbours, all play their part. No one in a police state ever responded to direct questions more warily than Azaro. "No" and "I don't know" are his default responses in conversation, which means that the dialogue in The Famished Road takes on a rebarbative quality of stonewalling. There are powerful rhetorical passages where characters state their dreams and visions, analyses and aspirations, but relatively little discussion and deep exchange between the characters. Emotional highs and lows subside in a few lines into a kind of passivity. Superhuman efforts on the part of Dad give way to lassitude and exhaustion.

The recent critical approaches by Bayer, Highfield and Barker, mentioned above, are rewarding, but can come to seem somewhat selective. There are so many contradictions, inconclusive patterns and rich dead ends that make up one's experience of reading The Famished Road: compelling passages alongside meandering ones, surprises and repetitiveness; repeated rhythms and patterns, fulfilled and frustrated "horizons of [reader] expectation," in Hans Robert Jauss's terms (23).

Chapter Two of Book Five, for example, combines many features of The Famished Road within an arena of battle and spiritual struggle, where contending human and spirit voices invade the fasting consciousness of Azaro. Having been thrashed by his father, Azaro retreats into a resentful refusal of food, a delirious consciousness in which he is competed for by a three-headed spirit that derides human capacities and ethics: "Humans don't care. They don't know how to love. They don't know what love is. Look at them. You are dying and all they do is polish their boots. Do they love you? No!" (326). In a section emblematic of the novel's spatial design, the spirit takes Azaro on an extended journey, while his body remains at home in his bed in the ghetto. The journey itself is strange in more ways than one, and subverts simple dichotomies between the spirit world and the human world. The road that Azaro sees en route, built laboriously 
and at a rate of two feet in two thousand years by spirits, seems to bring the two worlds closer together. These spirits and the human beings seem to share the fate of Sisyphus, rolling a huge rock up a hill only to see it career down the other side. But it is only one version of the road in the book, and it is hardly returned to again. Then Dad and Mum set up their own siren song: Mum's voice, that he senses "in [his] soul," loosens the silver cords attaching him to the spirit world (334) and Dad is inspired to voice his first great speech:

We are poor. We have little to give you, but our love. You came out of our deepest joy. We prayed for you. We wanted you. [...] Does this life not move you? When you play in the streets and see the children die, and hear the mothers weep, and hear the old ones sing of each miraculous birth, is your heart untouched? We have sorrow here. But we also have celebration. We know the special joys. (337)

Azaro's spirit guide, who insists on taking him back to his original home, is testy, grudging and eventually defeated by another (female) spirit, a mysterious guardian of the river. The spirit's opinions on the human capacity to love are proved wrong by events. The alternative world he passes through with Azaro contains illusions and threatening violence. Indeed his promises of eventual bliss and extended feasting are never put to the test, though Azaro's memories of the world from which he trails clouds of glory seem to bear out his promises. Dad's humanist credo expresses the human lot of suffering and joy, or joy within suffering, but also focuses on his fears that, as an abiku child, Azaro may prove heartless and unmoved by suffering: "They say $[\ldots]$ that you care nothing for your parents, that you are cold. [...] But I do not believe them. You have wept for us" (337). On the whole, this is what Azaro tends not to do, for the majority of the book. While he is impressed by his father and mother's various attempts to transcend their surroundings and support their family, his account is initially not remarkable for its tenderness or emotional depth. I must point out here that Ben Obumselu sees the book differently - more as a Bildungsroman, in fact ("At the end of the story, Azaro is a new person. [...] he wants 'to be a man,' carrying his part of the burden of the world" [Obumselu 4]). One of the things that holds me back from assenting fully to this position, though it does endorse the valorisation of human as opposed to abik $u$ spirituality that I see as important to the novel, is that Azaro's own narrative position is unstable. Is the book narrated from the perspective of a child, of an otherwordly spirit child, or of a fully developed and intellectualized one? Well, all three at different points. Thomas Martinek remarks on this "uneasy relationship between the experiencing self and the narrating self," but sees it as a virtue: "The result is a highly ambiguous and notoriously unreliable narrative that will challenge its readers" (n.p.). But who is speaking in Chapter Twelve of Book Seven?

The spirit-child is an unwilling adventurer into chaos and sunlight, into the dreams of the living and the dead. Things that are not ready, not willing to be born or to become, things for which adequate preparations have not been made to sustain their momentous births, things that are not resolved, things bound up with failure and with fear of being, they all keep recurring, keep coming back, and in themselves partake of the spirit child's condition. (558)

This sounds more like the narrator of Astonishing the Gods, or Lao's conclusion to In Arcadia, and suggests the somewhat problematic conflation of Azaro's and Okri's voices, as mentioned earlier. 
For me, for all its shifts of perspective and action, the reading experience of The Famished Road is dominated by material and spiritual journeys. Literally and metaphorically, the book is characterized by a sequence of departures and returns. On an allegorical level, this is reinforced at the end of the book by what Azaro describes as Dad's discovery that the nation and his son have something in common:

In his journeys Dad found that all nations are children; it shocked him that ours too was an abiku nation, a spirit-child nation, one that keeps being reborn and after each birth comes blood and betrayals, and the child of our will refuses to stay till we have made propitious sacrifice. (567)

And it is not just nations that keep on being reborn. Dad's boxing battles are successively fought, won, and fought again. The people's fickle admiration has to be won over and then lost. Journeys have to be taken towards the spirit world and then steps retraced. Feasts have to be eaten before descending into disruptive chaos and anarchy. Madame Koto has to shift from early struggles to prosperity. Her car is bought, then crashed. Political campaigns have to be waged repeatedly. The reader's horizons of expectation are changed slightly after each section and episode. Okri is endlessly inventive in re-staging these journeys, this to-and-fro movement, exhausting the reader and yet giving some sense of development. The turbulence and surprise-within-familiarity that characterizes the ebb and flow of the book is suggested early on. The following purports to be a description of the abiku "land of beginnings" beyond the material world:

We knew no boundaries. There was much feasting, playing and sorrowing. We feasted much because of the beautiful terrors of eternity. We played much because we were free. And we sorrowed much because there were always those amongst us who had just returned from the world of the Living. They had returned inconsolable for all the love they had left behind, all the suffering they hadn't redeemed, all that they hadn't understood, and for all that they had barely begun to learn. (3)

Successive new beginnings, false trials, experiences of suffering and celebration ... perhaps the spirit world is not that different from the human world, after all. Dad's incarnations, whether they be abject heroic labour, making monstrous demands on his body, or phenomenal feats of boxing half in and half out of the material world, move him nearer and nearer to both extinction and triumph. He becomes an Ogun hero of Titanic struggle (that is, both Nigerian and Classical), defying gods and spirits and using his winnings on quixotic schemes to benefit the poor. His kudos evaporates as he befriends the beggars, and gravitates towards "cranky" schemes that might just, in fact, be achievable. What kind of world does he dream of? One where everyone is educated and aware of the world, where children would be teachers and adults pupils, ${ }^{2}$ where regular fair elections are held in response to public demand. In the world of The Famished Road even the process of buying and reading books becomes exotic and worlds-spanning. Dad's new dictionary (bought for Azaro to consult, since Dad cannot read) "must have cost him at least twenty punches from the fist of the Green Leopard" (409).

The room became cluttered with books of all sizes, ugly books with pictureless covers and tiny letters as if intended for only the ants to read, large books that broke your back 
to carry them, books with such sloped lettering that they strained the neck, books which smelt like cobwebs and barks of medicinal trees and old sawdust after rain. (469-70)

This vivid passage is both exotic and homely, mysterious and mundane, and Dad's wish to be read into wisdom both heroic and far-seeing, and totally quixotic. Like all Dad's ventures and journeys, his devotion to books flares up for a while and then dwindles, first into the apparently-logical but doomed rubbish-clearing initiative (410) and then into another fight, this time with the man in the white suit, where Ade and Azaro become his seconds and helpers. He wins, but pays a heavy price in injuries to his body and sanity. He sleeps for three days and nights, "redreaming the world" and his spirit returns as a prophet with "a new deep sad voice": "In my sleep I saw many wonderful things" (497). One of these things is the realization that "Life is a great thing" (497). If one of Madame Koto's many incarnations is to be a "spirit-bride to heads of state and presidents," (496) Dad's is to become "a bigger man with a bigger madness" (497) with "the words of a stranger" (499) that have a transnational significance and leave us on the last page of the book with what could have been closure, and Azaro spending a night reconciled to human life and a human future, with his fears dissolved (500). But the next day has to follow and, ominously, "the good breeze hadn't lasted forever" (500) and the restless repeated movements of the book resume ... in the sequel, as it happens.

So the experience of reading The Famished Road is to set out on aborted journeys, to be moved and then have that emotion left in suspension as the book takes another turn; to witness with Azaro wonders of the spirit world, only to have them abruptly disappear and some new or repeated thread taken up. Mighty battles that could be climaxes to the text become stages in the journey, and have to be fought again. Insights are gained and half-surrendered. Over it all hangs the question that was to be taken up in In Arcadia and Astonishing the Gods, of how spirituality manifests itself within a world seething with opportunism, corruption, cronyism, poverty, bullying, and the operation of global capital that constantly threatens to disempower ordinary people and tempt them to negation and despair. It is sometimes forgotten just how "brilliant [a] satirist" Okri is, as Thomas Martinek reminds us. Azaro's very coolness and (at times) lack of affect, which mediates the world of the novel, makes him Okri's version of Voltaire's Candide, and he is seldom fooled by the multitude of self-serving individuals he meets, whether in spirit or fleshly form. What is remarkable, here as in Okri's later work, is the way that the book modulates between this forensic gaze and its anxious anticipations of the trials of nation-building in Nigeria, the dense and seemingly endless fecundity of the novel's actions and variations, and those moments when deep spirituality is the only way one can describe what is being experienced by Azaro and his indomitable family: those moments when, as Okri says at the end of In Arcadia: "living is the place where gods play within mortal flesh" (229-30). In the end, the paradox may be that the spirit world allegiances and affiliations that make Azaro a precarious member of the Nigerian nation and the human race are matched and even surpassed by the spirituality and divinity of the humans he finds himself amongst. Okri gives us a clue about this near the end of the book, when Azaro watches his fellow-abiku Ade resist his father's attempt to re-integrate him within his human family and realizes that "he did not want to stay any more" (486). There is something cruel, something relentless, in Ade's commitment to his version of the spirit world, and his stance in which "love and the anguish of parents 
touched him only faintly" (486). One day soon, he will be gone to his "greater home" (486). Azaro realizes that he and Ade may be "different," and though he does not work through explicitly to this statement, it maybe that the reader comes to consider, as Dad comes back to life from his dreams and utters his half-baffling, half-inspiring hymn to the human spirit and the future of Africa, that the boundaries of the "spirit world" have all along been more complex than Azaro's summary in the opening pages of the book allowed for.

Like other books by Okri, The Famished Road is a challenging account of a spiritual journey and the need to imagine beyond oneself and beyond one's immediate circumstances. Because of its complex, many-layered nature, there will continue to be interpretations that offer to map this journey as a national or political allegory. Many of these interpretations will be compelling and enlightening; but they will also continue to be partial, and to some extent limiting.

Christopher Ringrose

The University of Northampton

\section{Works Cited}

BARKer, Clare. Postcolonial Fiction and Disability: Exceptional Children, Metaphor and Materiality. London: Palgrave Macmillan, 2011.

BaKhtin, Mikhail M. The Dialogic Imagination: Four Essays. Ed. Michael Holquist. Austin: U of Texas P, 1982.

BAYER, Gerd. "The Spirit of Conviviality and the Demons of the Marketplace." The Famished Road: Ben Okri's Imaginary Homelands. Newcastle upon Tyne: Cambridge Scholars Press, 2013. 77-92.

Derrida, Jacques. Of Grammatology. Trans. G. C. Spivak. Baltimore: Johns Hopkins UP, 1997.

Fraser, Robert. Ben Okri. Tavistock, Devon: Northcote House, 2002.

Gilroy, Paul. After Empire: Multiculturalism and or Postcolonial Melancholia. London: Routledge. 2004.

Highfield, Jonathan. "No Longer Praying on Borrowed Wine: Agroforestry and Sovereignty in Ben Okri's Famished Road Trilogy." Environment at the Margins. Ed. B. CAminero-Santiago, and G. Myers. Athens, OH: U of Ohio P, 2012. 141-58.

Huyssen, Andreas. "Geographies of Modernism in a Globalizing World." Geographies of Modernism: Literatures, Cultures, Spaces. Ed. Peter Brooker, and Andrew Thacker. London: Routledge, 2005. 6-18.

IsER, Wolfgang. The Implied Reader. Baltimore: Johns Hopkins UP, 1974.

Jameson, Fredric. "Third-World Literature in the Era of Multinational Capitalism." Social Text 15 (1986): 68-88.

Levin, Stephen M. "A Conspiracy of Forms: Allegories of Capital in Amit Chaudhuri's The Immortals." Unpublished manuscript.

MARTINEK, Thomas. "The Famished Road." The Literary Encyclopedia 8 July 2004. <http://www.litencyc. $\mathrm{com} / \mathrm{php} /$ sworks.php? rec=true\&UID=889>. Accessed on 8 January 2013.

McCabe, Douglas. "Higher Realities: New Age Spirituality in Ben Okri's The Famished Road." Research in African Literatures 36.4 (2005): 1-21.

Mrtchell, David T., and Sharon L. Snyder. Cultural Locations of Disability. Chicago: U of Chicago P, 2000.

Obumselu, Ben. "Ben Okri's The Famished Road: A Re-evaluation.” Tydskrif vir Letterkunde 48.1 (2011): 26-38.

Okri, Ben. Astonishing the Gods. 1995. London: Phoenix House, 1996.

—. A Time for New Dreams. London: Rider Books, 2011.

—. Dangerous Love. 1996. London: Phoenix House, 1997.

—.The Famished Road. 1991. London: Vintage, 2003.

—. In Arcadia. 2002. London: Phoenix House, 2003.

PorDZIK, Ralph. "An African Utopographer: Ben Okri's Astonishing the Gods and the Quest for Postcolonial Utopia." Zeitschrift für Anglistik. und Americanistik. 48.1 (2000): 44-56. 
Quayson, Ato. Strategic Transformations in Nigerian Writing: Orality and History in the Work of Rev. Samuel Johnson, Amos Tutuola, Wole Soyinka, and Ben Okri. Oxford: James Currey, 1997.

Ringrose, Christopher. “Assessing Ben Okri's Fiction 1995-2005.” British Fiction Today. Ed. Philip Tew, and Rod Mengham. London: Continuum, 2006. 78-90.

Sмiтн, Andrew. "Ben Okri and the Freedom Whose Walls are Closing In." Race \& Class 47.1 (2005): $1-13$. 